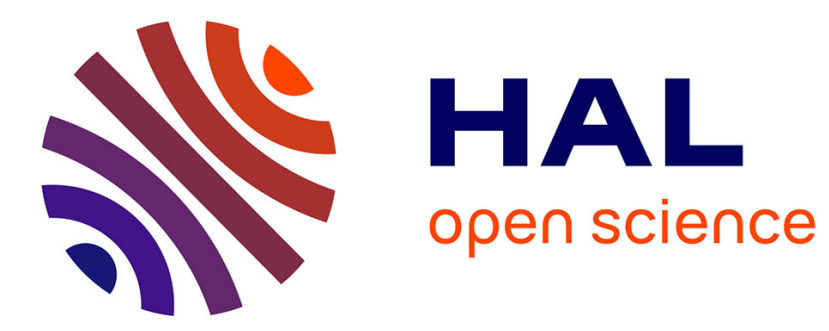

\title{
The first Palaeogene galliform from Africa
}

Cécile Mourer-Chauviré, Martin Pickford, Brigitte Senut

\section{To cite this version:}

Cécile Mourer-Chauviré, Martin Pickford, Brigitte Senut. The first Palaeogene galliform from Africa. Journal für Ornithologie $=$ Journal of Ornithology, 2010, 152 (3), pp.617-622. 10.1007/s10336-0100630-9 . hal-00652646

\section{HAL Id: hal-00652646 https://hal.science/hal-00652646}

Submitted on 16 Dec 2011

HAL is a multi-disciplinary open access archive for the deposit and dissemination of scientific research documents, whether they are published or not. The documents may come from teaching and research institutions in France or abroad, or from public or private research centers.
L'archive ouverte pluridisciplinaire HAL, est destinée au dépôt et à la diffusion de documents scientifiques de niveau recherche, publiés ou non, émanant des établissements d'enseignement et de recherche français ou étrangers, des laboratoires publics ou privés. 
Cécile Mourer-Chauviré ${ }^{1}$, Martin Pickford ${ }^{2,3}$ and Brigitte Senut ${ }^{3}$

\section{The first Palaeogene Galliform from Africa}

1 Université de Lyon, F-69622, Lyon, France ; Université Lyon 1, Villeurbanne; CNRS, UMR 5125, Paléoenvironnements et Paléobiosphère

2 Collège de France, Chaire d'évolution des climats et de l'océan

3 Muséum National d'Histoire Naturelle, Département Histoire de la Terre, CNRS, UMR 7207, Case postale 38, 8, rue Buffon, 75005 Paris

Corresponding author: Cécile Mourer-Chauviré

e-mail: cecile.mourer@univ-lyon1.fr

Tel : $33(0) 672570475$

Fax: $33(0) 472448382$ 


\begin{abstract}
An almost complete tarsometatarsus from the middle Eocene locality of Silica South, Sperrgebiet, Namibia, is attributed to the order Galliformes. This is the earliest record of the order in Africa. It belongs to a stem group galliform and differs from the Recent families. It is compared with Mesozoic birds from America, and Gallinuloididae, Quercymegapodiidae and Paraortygidae from Europe and the Americas. Because the specimen is an isolated bone, damaged proximally, we do not attribute it to a family, but it is clear that it represents a new genus and species of galliform bird, which we name Namaortyx sperrgebietensis.
\end{abstract}

Keywords Fossil bird, Galliform, Eocene, Namibia, stem lineage, Namaortyx sperrgebietensis

\title{
Zusammenfassung
}

\section{Der erste paläogene Hühnervogel aus Afrika}

Ein nahezu vollständiger Tarsometatarsus aus der lutetischen Fundstelle Silica South, Sperrgebiet, Namibia, wird der Ordnung Galliformes zugeordnet. Das Fossil ist der älteste Nachweis dieser Ordnung in Afrika. Das Material wird mit mesozoischen Vögeln von Amerika verglichen sowie mit den Gallinuloididae, Quercymegapodiidae und Paraortygidae aus Europa und Amerika. Weil das Exemplar ein isolierter, proximal beschädigter Knochen ist, ordnen wir ihn nicht einer Familie zu, aber es ist offensichtlich, dass es eine neue Gattung und Art galliformer Vögel repräsentiert, die wir Namaortyx sperrgebietae nennen. 


\section{Introduction}

During the Palaeogene the order Galliformes is represented in the Northern hemisphere, as well as in South America, by several extinct families which belong to stem group galliforms, while the recent families, the crown group galliforms, are unambiguously known only from the Late Oligocene for the Phasianidae and Megapodiidae, and later for the other families (Mayr 2009). Until now no galliform had ever been recorded for the Palaeogene of Africa, and the earliest galliforms known so far from this continent were the Early Miocene phasianids from the localities of Elisabethfeld and Grillental, Northern Sperrgebiet, Namibia (Mourer-Chauviré 2008).

The tarsometatarsus discovered at Silica South can be attributed to the order Galliformes because it presents on the plantar face two well developed fossae, on both sides of the hypotarsus, and because on the plantar face of trochlea met. III the lateral ridge protrudes farther proximally than the medial ridge, which is a characteristic feature of the Galliformes (Mayr 2000).

The locality of Silica South was discovered in 2008 by the Namibia Palaeontology Expedition. It is situated in the Sperrgebiet, in the southwest of Namibia, at approximately $27^{\circ} 16^{\prime} \mathrm{S}$ and $15^{\circ} 25^{\prime} \mathrm{E}$ (Pickford et al. 2008a). It is an almost circular outcrop of well bedded freshwater limestone. The basal layers of carbonates have been partly silicified and have yielded vertebrate fossils. The dating of this locality is founded on the mammalian fauna which includes hyracoids and rodents. Its age is probably Early Lutetian (Pickford et al. 2008b).

\section{Methods}

Osteological terminology follows Baumel and Witmer (1993) and when necessary Howard (1929). The fossil specimen is deposited in the Geological Survey of Namibia, Windhoek, Namibia.

\section{Results}

Systematic paleontology

\section{Order Galliformes TEMMINCK 1820}

Family incertae sedis

Genus Namaortyx nov.

Type species. Namaortyx sperrgebietensis

Diagnosis. Tarsometatarsus with splayed trochleae. Trochlea met. II slightly shorter than trochlea met. IV. Crista medianoplantaris reaching the wing of trochlea met. IV and not forked at its distal end. Shaft wide and flattened in section. In distal view trochleae disposed along an asymmetrical curve and trochlea met. III obliquely oriented compared to the dorsal surface of the shaft.

Derivatio nominis. Nama, from the region of discovery, and ortyx, Greek name for a quail.

Species Namaortyx sperrgebietensis nov. 
Fig. 1a-c

Holotype. $\mathrm{n}^{\circ} \mathrm{SS}$ 8’08, right tarsometatarsus, almost complete.

Type locality. Silica South, Sperrgebiet, Namibia

Age. Middle Eocene, probably Early Lutetian, about 47-49 million years ago.

Diagnosis. As for the genus

Derivatio nominis. For the Sperrgebiet, German name meaning "Forbidden Area"

Description and Comparisons

Right tarsometatarsus. The proximal articular surface and a part of the shaft, which is obliquely broken, are missing. The lateral side is more completely preserved than the medial side. The shaft is wide and flattened. At the distal part trochleae met. II and IV are splayed. On the dorsal surface the outer extensor groove (Howard 1929) is weakly expressed. The opening of the distal vascular foramen is large and situated just proximally to the lateral intertrochlear notch. The dorsal surfaces of trochleae met. II and III are slightly eroded. Trochlea met. IV is incompletely preserved but its wing is present, while the wing of trochlea met. II is missing. Trochlea met. III is the longest, then comes trochlea met. IV, while trochlea met. II is slightly shorter than trochlea met. IV.

On the plantar surface, the hypotarsus is not preserved. The two fossae parahypotarsales, characteristic of the Galliformes, are present on each side of the crista medianoplantaris. Only the lateral proximal vascular foramen can be seen. At the distal part, the crista medianoplantaris reaches the wing of trochlea met. IV and does not fork. The crista plantaris medialis reaches the level of fossa metatarsi I, then follows the medial border of this fossa, then reaches the wing of trochlea met. II. The fossa supratrochlearis plantaris is wide and shallow, and does not show any ridge, but only a small groove which joins the distal vascular foramen. Fossa met. I is very proximodistally elongated, which indicates that the processus articularis tarsometatarsalis was elongated. The lateral rim of trochlea met. III protrudes farther proximally than the medial rim. In distal view, the trochleae are not disposed along an arc, but along an asymmetrical curve, the apex of which corresponds to the dorsolateral angle of the bone. Dorsoplantarly trochlea met. III is oriented not perpendicularly to the dorsal surface of the shaft, but obliquely.

Comparison with the Recent galliform families

The tarsometatarsus from Silica South differs from the Recent families Numididae, Odontophoridae, and Phasianidae (including the Arborophilinae, Phasianinae, Tetraoninae, Meleagridinae, Coturnicinae, Pavoninae, and Gallininae) because in these families trochleae met. II and met. IV are not splayed. In addition trochlea met. II is distinctly shorter than trochlea met. IV and is plantarly displaced (Ksepka 2009). It also differs from the Cracidae because in the Cracidae the trochleae are not splayed but situated close together (Ksepka 2009). It is more similar to the Megapodiidae because it is the only Recent galliform family in 
which the trochleae are splayed, and in which trochlea met. II is almost the same length as trochlea met. IV (Ksepka 2009). However it differs from it because in distal view the trochleae are disposed along an asymmetrical curve, and because trochlea met. III is oriented obliquely compared to the dorsal surface of the shaft. By comparison with Eocene stem group Galliformes, the characters "splayed trochleae" and "trochlea met. II almost the same length as trochlea met. IV" present in the Namibian fossil can be identified as the plesiomorphic condition for Galliformes.

\section{Comparison with Mesozoic and early Tertiary forms}

In the late Cretaceous of North America the genus Palintropus has been tentatively assigned to Galliformes (Hope 2002) but Longrich (2009) has described further material of this genus and assumed that it does not belong to the Neornithes. The tarsometatarsus of this genus is unknown. Clarke (2004) has attributed to the Pangalliformes a distal tarsometatarsus which was the holotype of the species Ichthyornis lentus (Marsh 1877), from the Upper Cretaceous of Texas. This tarsometatarsus is attributed to the new taxon Austinornis. Unfortunately the provenance of this material is not accurately known. In Austinornis the lateral rim of trochlea met. III extends farther proximally than the medial rim. On the plantar surface there are two intermuscular lines. One runs along the lateral edge of the shaft; the second, situated more medially, corresponds to the crista medianoplantaris. It seems that it does not fork (see Clarke 2004, fig. 17). It differs from Namaortyx because its trochlea met. II is much shorter and more plantarly displaced. Hwang et al. (2010) have reported a very small galliform from the late Palaeocene or early Eocene of Mongolia, but it is only known by a fragment of humerus. Lindow and Dyke (2007) have attributed to Galliformes incertae sedis a pair of fossilized imprints of feet, from the Lower Eocene Fur Formation of Denmark. The authors write that the trochleae "for digits II and III are approximately equally extended distally" (p. 62) but it is unlikely and they probably intended to write "for digits II and IV". These tarsometatarsi differ from Namaortyx by their very elongate and slender shapes.

\section{Comparison with the Gallinuloididae}

Gallinuloididae are known from the early and middle Eocene, with Gallinuloides wyomingensis from the early Eocene of the United States, Paraortygoides radagasti, from the early Eocene of England, and $P$. messelensis, from the middle Eocene of Germany (Mayr 2000, 2006, 2008, 2009; Mayr and Weidig 2004; Dyke and Gulas 2002; Ksepka 2009; Weidig 2010).

In both specimens of Gallinuloides wyomingensis it is not possible to see the plantar surface of the tarsometatarsi, but in distal view the trochleae are disposed along a curved line, and trochlea met. II is considerably shorter than trochlea met. IV (Weidig 2010) while in Paraortygoides messelensis trochlea met. II is slightly shorter than trochlea met. IV (Mayr 2000). In Paraortygoides messelensis three ridges are present on the plantar surface of the tarsometatarsus, a medial one, a lateral one, and a crista medianoplantaris which forks at the level of fossa met. I. It forks and reaches both wings of trochleae met. II and IV, while in Namaortyx it does not fork and reaches only the wing of trochlea met. IV. On the distal part 
of tarsometatarsus attributed to $P$. radagasti, the crista medianoplantaris is not visible (see Dyke and Gulas 2002, fig. 2, F and fig. 4, B, and Mayr 2009, fig. 6.4, i).

In the genera Gallinuloides and Paraortygoides the processus articularis of os metacarpale I is very short.

The genus Namaortyx differs from the Gallinuloididae by the wide and flattened shape of the shaft, the disposition of the trochleae along an asymmetrical curve, the presence of an unforked crista medianoplantaris, and the presence of a very elongated fossa articularis met. I.

Comparison with the Quercymegapodiidae

Quercymegapodiidae have been known from the Middle Eocene (localities of Le Bretou and Lavergne, Phosphorites du Quercy, France), to the late Oligocene or early Miocene of Brazil, and the early Miocene of France, with the genera Quercymegapodius and Ameripodius (Mourer-Chauviré 1988, 1992, 2000, 2006; Alvarenga 1988, 1995). In the locality of Le Bretou a very small galliform was referred to the family Gallinuloididae and tentatively attributed to the genus Taoperdix (Mourer-Chauvire 1988, 1992, 2006), because the genus Taoperdix was then considered to be a Gallinuloididae (Brodkorb 1964; Ballmann 1969). More recently Mayr and Weidig (2004) have shown that the type species of Taoperdix, T. pessieti, is not a Gallinuloididae and Mayr (2009) suggests that it may be a Paraortygidae. The descriptions of new specimens of Gallinuloididae (Mayr 2000; Mayr and Weidig 2004) show that this very small galliform from Quercy does not correspond to a Gallinuloididae but to a Quercymegapodiidae. The form from Le Bretou cannot be compared directly to the small species $Q$. brodkorbi, as the tarsometatarsus of the latter species is not known. When compared to the large species $Q$. depereti, for which the tarsometatarsus is known, the form from Le Bretou is metrically slightly smaller than Q. brodkorbi. It is designated here as Quercymegapodius cf. brodkorbi.

In Quercymegapodius, as in Namaortyx, the distal trochleae are splayed.

Quercymegapodius shows the same disposition of the crista medianoplantaris, which does not fork, and of the medial plantar ridge. The fossa supratrochlearis plantaris is wide and shallow. The distal vascular foramen has a wide opening, fossa met. I is very elongate. Namaortyx differs from Quercymegapodius by the wide and flattened shape of the shaft, and by the disposition of the trochleae in distal view.

Few morphological details are visible on the tarsometatarsus of Ameripodius granivora (Alvarenga 1988), and the tarsometatarsus is not preserved in A. silvasantosi (Alvarenga 1995), both from Taubaté, Brazil, but the tarsometatarsus is known in A. alexis, from the early Miocene of Saint-Gérand-le-Puy, France (Mourer-Chauviré 2000). On the plantar surface the crista medianoplantaris is well marked and reaches the wing of trochlea met. II. On adult specimens it shows a very slight bifurcation, laterally directed, at the level of the distal part of fossa met. I, but this bifurcation is absent on a subadult specimens. The Namaortyx tarsometatarsus differs from that of Ameripodius by its short and wide shaft, while it is long and slender in Ameripodius, and by the disposition of the trochleae. 
Comparison with the Paraortygidae

The Paraortygidae are known in the middle and late Eocene of the Phosphorites du Quercy, France, and the early Oligocene of Germany (Mourer-Chauviré 1992; Fischer 1990, 2003). They are also probably present in the late Eocene and the early Oligocene of the United States (Mayr 2009). Namaortyx differs from the Paraortygidae because in the latter, trochlea met. II is situated farther in the proximal direction, and it is strongly plantarly displaced. On the dorsal surface, the distal vascular foramen is situated at the end of a deep outer extensor groove, while this groove is weakly indicated in Namaortyx. On the plantar side, the displacement of trochlea met. II leads to a narrowing of the fossa supratrochlearis plantaris, a large part of which is occupied by the wide opening of the distal vascular foramen. Fossa met. I extends distally onto the proximal part of the wing of trochlea met. II. The crista medianoplantaris is situated closer to the lateral plantar ridge than to the medial plantar ridge, and it forks at its distal end.

\section{Discussion}

Namaortyx shows some similarities with the extinct genus Quercymegapodius, and the recent genus Megapodius, but these similarities are probably plesiomorphic characteristics for the Galliformes. Some of them are also present in Austinornis, a probable galliform from the late Cretaceous of Texas (Clarke 2004). It would be very interesting to have other skeletal elements which could be associated with this tarsometatarsus, such as the coracoid or the humerus. In the absence of these elements we prefer to leave the genus Namaortyx in Family incertae sedis. Cracraft (2001) put forward the hypothesis that the galliforms would have diversified on the southern supercontinent Gondwana (South America, Africa, India, and Australia). This hypothesis is founded on the fact that, amongst the Recent crown group galliforms, the two most primitive families, i. e. the Megapodiidae and the Cracidae, are predominantly distributed in the southern Hemisphere. However galliforms are not present in the Palaeocene and early Eocene fossiliferous localities known in India, Australia, and South America (Mayr et al. 2007; Mayr 2009). In Africa the only fossil birds described so far in the Palaeocene and early Eocene belong to marine families (Bourdon 2006, Bourdon et al. 2005, 2008a, 2008b).The occurrence of a galliform in the early middle Eocene of Namibia does not bring an argument in favour of Cracraft's hypothesis because primitive stem group galliforms were present in the Northern Hemisphere as early as the Cretaceous (Austinornis), the late Palaeocene or early Eocene of Mongolia (Hwang et al. 2010), and the early Eocene of Europe and North America (Gallinuloididae) (Mayr 2009). The fossil record of the galliforms is still considerably older in the Northern Hemisphere than it is in Gondwana. Crowe et al. (2006) from morphological and molecular data of the Recent forms provided strong arguments for an African origin of the Numididae, Odontophoridae, and Phasianidae, but, again, the Namibian form does not bring an argument in favour of this hypothesis because it belongs to a stem group galliform and cannot be considered as an early representative of a crown group galliform.

Measurements (in mm) of the $\mathrm{n}^{\circ} \mathrm{SS} 8^{\prime} 08$, right tarsometatarsus, type specimen of Namaortyx sperrgebietensis. 
Total length (as preserved), 54.2; total length estimated, ca. 56; width of shaft in the middle, 6.2; maximum depth on the lateral side, 4.2; maximum depth of the medial side, 3.4; distal width as preserved, 11.9; depth of the lateral rim of the trochlea met. III, 6.7; depth of the trochlea met. IV including the wing, 8.0

Acknowledgements For the loan of comparative material we thank Christine Lefèvre from the Laboratoire d'Anatomie comparée of the Muséum national d'Histoire Naturelle, Paris. We thank the Geological Survey of Namibia (G. Schneider) and the Namibian National Monuments Council (E. Ndalikokule) for authorisation to conduct research in Namibia, and Namdeb (J.J. Jacob) for administrative and logistic help in the Sperrgebiet. Support was obtained from UMR 7207 CNRS and the Service de Coopération et d'action culturelle of the French Embassy at Windhoek. We thank G. Mayr and an anonymous referee for critical comments which improved this paper.

\section{References}

Alvarenga HMF (1988) Ave fóssil (Gruiformes: Rallidae) dos folhelhos da Bacia de Taubaté, Estado de São Paulo, Brasil. An Acad bras Cien 60: 321-32.

Alvarenga HMF (1995) Um Primitivo Membro da Ordem Galliformes (Aves) do Terciário Médio da Bacia de Taubaté, Estado de São Paulo, Brasil. An Acad bras Cien 67: 33 44

Ballmann P (1969) Die Vögel aus der altburdigalen Spaltenfüllung von Wintershof (West) bei Eichstätt in Bayern. Zitteliana, 1: 5-60

Baumel JJ, Witmer LM (1993) Osteologia. In: Baumel JJ, King AS, Breazile JE, Evans HE, Vanden Berge JC (eds) Handbook of avian anatomy: nomina anatomica avium. Pub Nuttall Ornithol Club 23: 45-132

Bourdon E (2006) L'avifaune du Paléogène des phosphates du Maroc et du Togo: diversité, systématique et apports à la connaissance de la diversification des Oiseaux moderns (Néornithes). $\mathrm{PhD}$ thesis, Muséum national d'Histoire naturelle, Paris.

Bourdon E, Bouya B, Iarochène M (2005) Earliest African neornithine bird : a new species of Prophaethontidae (Aves) from the Paleocene of Morocco. J Vertebr Paleontol 25: 157-170

Bourdon E, Amaghzaz M, Bouya B (2008a) A new seabird (Aves, cf. Phaethontidae) from the Lower Eocene phosphates of Morocco. Geobios 41: 455-459

Bourdon E, Mourer-Chauviré C, Amaghzaz M, Bouya B (2008b) New specimens of Lithoptila abdounensis (Aves, Prophaethontidae) from the Lower Paleogene of Morocco. J Vertebr Paleont 28:751-761

Brodkorb P (1964) Catalogue of fossil birds. Part 2 (Anseriformes through Galliformes). Bull Fla State Mus Biol Sci 8 (3): 195-335

Clarke JA (2004) Morphology, phylogenetic taxonomy, and systematics of Ichthyornis and Apatornis (Avialae: Ornithurae). Bull Amer Mus Nat Hist 286:1-179

Cracraft J (2001) Avian evolution, Gondwana biogeography and the Cretaceous-Tertiary mass extinction event. Proc R Soc Lond B 268:459-469 
Crowe TM, Bowie RCK, Bloomer P, Mandiwana TG, Hedderson TAJ, Randi E, Pereira SL, Wakeling J (2006) Phylogenetics, biogeography and classification of, and character evolution in, gamebirds (Aves: Galliformes): effects of character exclusion, data partitioning and missing data. Cladistics 22:495-532

Dyke GJ, Gulas BE (2002) The fossil Galliform Bird Paraortygoides from the Lower Eocene of the United Kingdom. Am Mus Novit 3360:1-14

Fischer K (1990) Der Hühnervogel Pirortyx major (Gaillard, 1939) aus dem marinen Mitteloligozän bei Leipzig (DDR). Mitt Zool Mus Berlin 66 (Suppl Ann Ornithol 14): $133-136$

Fischer K (2003) Weitere Vogelknochen von Diomedeoides (Diomedeoididae, Procellariiformes) und Paraortyx (Paraortygidae, Galliformes) aus dem Unteroligozän des Weisßelsterbeckens bei Leipzig. Mauritiana 18: 387-395

Hope S (2002) The Mesozoic radiation of Neornithes. In: Chiappe LM, Witmer LM (eds) Mesozoic birds: above the heads of dinosaurs. University of California Press, Berkeley: 339-388

Howard H (1929) The avifauna of Emeryville shellmound. Univ Calif Publ Zool 32: 301394

Hwang SH, Mayr G, Bolortsetseg M (2010) The earliest record of a galliform bird in Asia, from the late Paleocene-early Eocene of the Gobi Desert, Mongolia. J Vertebr Paleontol, 30: 1642-1644

Ksepka DT (2009) Broken gears in the avian molecular clock: new phylogenetic analyses support stem galliform status for Gallinuloides wyomingensis and rallid affinities for Amithaba urbsinterdictensis. Cladistics 25: 173-197

Lindow BEK, Dyke GJ (2007) A small galliform bird from the Lower Eocene Fur Formation, north-western Denmark. Bull Geol Soc Den 55: 59-63

Longrich N (2009) An ornithurine-dominated avifauna from the Belly River Group (Campanian, Upper Cretaceous) of Alberta, Canada. Cretac Res3: 161-177

Marsh OC (1877) New fossil vertebrates. Amer J Sci $3{ }^{\text {rd }}$ Ser 14:249-256

Mayr G (2000) A new basal galliform bird from the Middle Eocene of Messel (Hessen, Germany). Senckenberg Lethaea, 80: 45-57

Mayr G (2006) New specimens of the early Eocene stem group galliform Paraortygoides (Gallinuloididae), with comments on the evolution of a crop in the stem lineage of Galliformes. J Ornithol 147: 31-37

Mayr G (2008) The fossil record of galliform birds: comments on Crowe et al. (2006). Cladistics 24: 74-76

Mayr G (2009) Paleogene Fossil Birds. Springer-Verlag, Berlin Heidelberg

Mayr G, Rana RS, Sahni A, Smith T (2007) Oldest fossil avian remains from the Indian subcontinental plate. Crr Sci 92: 1266-1269

Mayr G, Weidig I (2004) The Early Eocene bird Gallinuloides wyomingensis - a stem group representative of Galliformes. Acta Palaeontol Pol 49: 211-217

Mourer-Chauviré C (1988) Le gisement du Bretou (Phosphorites du Quercy, Tarn-etGaronne, France) et sa faune de vertébrés de l'Eocène supérieur. II oiseaux. Palaeontographica A 205: 29-50 
Mourer-Chauviré C (1992) The Galliformes (Aves) from the Phosphorites du Quercy (France): systematics and biostratigraphy. In : Campbell KE (ed) Papers in avian paleontology honoring Pierce Brodkorb. Nat Hist Mus Los Angeles Cty Sci Ser 36: 67-95

Mourer-Chauviré C (2000) A new species of Ameripodius (Aves: Galliformes:

Quercymegapodiidae) from the Lower Miocene of France. Palaeontology 43: 481493

Mourer-Chauviré C (2006) The avifauna of the Eocene and Oligocene Phosphorites du Quercy (France): An updated list. Strata Ser 1 13: 135-149

Mourer-Chauviré C (2008) Birds (Aves) from the Early Miocene of the Northern Sperrgebiet. Mem Geol Surv Namibia 20: 147-167

Pickford M, Senut B, Morales J, Sanchez IM (2008a) Fossiliferous Cainozoic Carbonates of the Northern Sperrgebiet. Mem Geol Surv Namibia 20: 25-42

Pickford M, Senut B, Morales J, Mein P, Sanchez IM (2008b) Mammalia from the Lutetian of Namibia. Mem Geol Surv Namibia 20: 465-514

Weidig I (2010) New Birds from the Lower Eocene Green River Formation, North America. In: Boles WE, Worthy TH (eds) Proceedings of the VII international meeting of the Society of Avian Paleontology and Evolution. Rec Aust Mus 62: 29-44 


\section{Caption of figure}

Fig. 1a-c Namaortyx sperrgebietensis, nov. gen. nov. sp. a Right tarsometatarsus, ${ }^{\circ}$ SS 8'08, holotype, dorsal view. b Idem, plantar view. c Idem, distal view. Scale bars equal $1 \mathrm{~cm}$ 